
S0102-053620190308

\title{
Herbicide selectivity for potato crop
}

\author{
Núbia M Correia ${ }^{1 \mathbb{D}}$; Agnaldo DF Carvalho' ${ }^{\mathbb{D}}$
}

${ }^{1}$ Embrapa Cerrados, Brasília-DF, Brasil; nubia.correia@embrapa.br (corresponding author); ${ }^{2}$ Embrapa Hortaliças, Brasília-DF, Brasil; agnaldo.carvalho@embrapa.br

\begin{abstract}
Few studies on herbicide selectivity for potato crop can be found in literature, especially under Brazilian conditions. Therefore, the aim of this study was to analyze phytotoxic action of different herbicides for potato cv. Agata. Two experiments were developed under commercial field production conditions. A randomized complete block design, in factorial scheme $7 \times 2+1$, four replicates, was used, from April 14 to September 29, 2016. Treatments consisted of seven herbicides sprayed at two doses (ethoxysulfuron 45 and 90 $\mathrm{g} \mathrm{ha}^{-1}$, halosulfuron 37.5 and $75 \mathrm{~g} \mathrm{ha}^{-1}$, sulfentrazone 250 and $500 \mathrm{~g}$ $\mathrm{ha}^{-1}$, flumioxazin 17.5 and $35 \mathrm{~g} \mathrm{ha}^{-1}$, clomazone 200 and $400 \mathrm{~g} \mathrm{ha}^{-1}$, isoxaflutole 37.5 and $75 \mathrm{~g} \mathrm{ha}^{-1}$ and oxadiazon 250 and $500 \mathrm{~g} \mathrm{ha}^{-1}$ ) and also a control without application. Potato plants were sprayed with post-emergence herbicide ethoxysulfuron, four and seven days after hilling up, for the first and the second experiments, respectively; the other pre-emergence herbicides were sprayed after planting. The two doses of herbicide ethoxysulfuron caused severe visual injuries to potato plants, reflected in the commercial production of tubers. However, flumioxazin, halosulfuron, sulfentrazone, clomazone, isoxaflutole and oxadiazon were considered promising pre-emergence herbicides for potato crop.
\end{abstract}

Keywords: Solanum tuberosum, cv. Agata, phytotoxicity, tolerance.

\section{RESUMO}

\section{Seletividade de herbicidas para a cultura da batata}

Estudos sobre seletividade de herbicidas para a cultura da batata são poucos, especialmente em condições brasileiras. Por isso, objetivou-se estudar a ação fitotóxica de diferentes herbicidas para a cultura da batata, cv. Agata. Dois experimentos foram desenvolvidos em área de produção comercial, no delineamento experimental de blocos ao acaso, em esquema fatorial $7 \times 2+1$, em quatro repetições, de 14 de abril a 29 de setembro de 2016. Os tratamentos foram constituídos da aplicação de sete herbicidas em duas dosagens (ethoxysulfuron 45 e $90 \mathrm{~g} \mathrm{ha}^{-1}$, halosulfuron $37,5 \mathrm{e} 75 \mathrm{~g} \mathrm{ha}^{-1}$, sulfentrazone 250 e $500 \mathrm{~g} \mathrm{ha}^{-1}$, flumioxazin 17,5 e $35 \mathrm{~g} \mathrm{ha}^{-1}$, clomazone 200 e $400 \mathrm{~g}$ $\mathrm{ha}^{-1}$, isoxaflutole 37,5 e $75 \mathrm{~g} \mathrm{ha}^{-1}$ e oxadiazon 250 e $500 \mathrm{~g} \mathrm{ha}^{-1}$ ), além de uma testemunha sem aplicação. O herbicida ethoxysulfuron foi pulverizado em pós-emergência nas plantas de batata, 4 e 7 dias após a realização da amontoa, respectivamente para primeiro e segundo experimento; e os demais em pré-emergência, após o plantio da batata. As duas dosagens de ethoxysulfuron ocasionaram injúrias visuais severas às plantas de batata, com reflexo na produção comercial de tubérculos. Entretanto, flumioxazin, halosulfuron, sulfentrazone, clomazone, isoxaflutole e oxadiazon foram promissores para uso na cultura em pré-emergência.

Palavras-chave: Solanum tuberosum, cv. Agata, fitotoxicidade, tolerância.

\section{Received on November 29, 2018; accepted on August 2, 2019}

A ccording to potato growers, chemical weed control in potato crop in the Southeast and Midwest regions of Brazil (São Paulo, Goiás and Triângulo Mineiro) is made by using pre-emergence herbicide metribuzin, and, when necessary, post-emergence herbicides belonging to aryloxyphenoxypropionate and cyclohexanedione chemical groups, specific to control species of Poaceae family.

Despite the simplicity of herbicide selection, weed management in agricultural areas is not as easy. Species belonging to family Solanaceae, such as Solanum americanum and Nicandra physaloides represent a great problem, since herbicide metribuzin is not effective for its management; it is not effective enough for Cyperus rotundus, Oxalis spp. and Polygonum convolvus, which dominate the cropping areas. $P$. convolvus became common in irrigated potato production areas in Cristalina, GO and Araxá, MG and, due to various emergency flows throughout the crop cycle, allied to its climbing growth habit (Lorenzi, 2008), causes damages to potato during the root mechanized harvesting.

According to this panorama of infestation, we conclude that weed management in potato crop using just one or two herbicides is quite difficult. New strategies should be adopted, considering an integrated management system or, simply, the use of other herbicides which are not used, despite being registered for the crop. For instance, clomazone, isoxaflutole and flumioxazin which are herbicides suggested for pre emergency application after planting (Rodrigues \& Almeida, 2018; Agrofit, 2019).

Clomazone and isoxaflutole have a broader spectrum control of grass species, registered at doses 360 and $75 \mathrm{~g} \mathrm{ha}^{-1}$ for potato crop, respectively; flumioxazin is registered to control, mainly, eudicotyledons, at the dose 35 
$\mathrm{g} \mathrm{ha}^{-1}$ (Rodrigues \& Almeida, 2018, Agrofit, 2019). Flumioxazin is a quite promising herbicide for this crop, based on the results in controlling solanaceous species, reported in other studies (Kazarian et al., 2000; Wilson et al., 2002; Hutchinson, 2007) and selectivity for potato crop at doses of up to $72 \mathrm{~g} \mathrm{ha}^{-1}$ (Wilson et al., 2002; Vasilakoglou et al., 2013).

Based on the control potential of problematic weeds in potato crop, ethoxysulfuron, halosulfuron, sulfentrazone and oxadiazon herbicides are recommended. The three first mentioned herbicides are excellent for cyperaceous control, such as $C$. rotundus (Gannon et al., 2012; Boyd, 2015); oxadiazon is effective for Oxalis spp. and solanaceous, and it is also recommended for other vegetables, such as onion and garlic (Rodrigues \& Almeida 2018; Agrofit, 2019). Sulfentrazone and halosulfuron are widely studied in other countries for potato crop, for weed management and selectivity for the crop (Bailey et al., 2002, Wilson et al., 2002; Grichar et al., 2003; Hutchinson et al., 2005a,b and 2006; Boydston, 2007).

Results of weed management using herbicides is important, selectivity or its phytotoxic action in a crop of economic interest should also be considered, since the herbicide chosen should be effective for weed and selective for the crop, without affecting productive potential. Selectivity is the base for a successful chemical control of weeds in agricultural production, considering a measure of a differential response of various plant species to a given herbicide. The greater the tolerance, differences between crop and weed, the greater the application safety (Oliveira Junior \& Inoue, 2011).

As variation in phytotoxic action of ethoxysulfuron, halosulfuron, sulfentrazone, flumioxazin, clomazone, isoxaflutole and oxadiazon herbicides in potato plants could be noticed, the aim of this study was to evaluate the selectivity of these herbicides for potato crop.

\section{MATERIAL AND METHODS}

Two experiments were conducted in the commercial production area of potato cv. Agata, in the municipalities Cristalina-GO and Unaí-MG, from April 14 to September 29, 2016. Cultivar Agata was chosen for the tests for being the most planted cultivar in the country to be consumed in natura.

According to Köppen, the local climate is Aw, tropical with dry winter (Cardoso et al., 2014; Simões et al., 2015). Soil in experimental areas (16 $24^{\circ} 35^{\prime}$ 'S, 47 $7^{\circ} 16^{\prime} 24^{\prime \prime} \mathrm{O}, 981 \mathrm{~m}$ altitude and $16^{\circ} 5^{\prime} 12^{\prime \prime} \mathrm{S}, 47^{\circ} 27^{\prime} 55^{\prime \prime} \mathrm{O}$, $970 \mathrm{~m}$ altitude) is representative of the region, classified as Dark-Red Latosol, presenting values of $\mathrm{pH}\left(\mathrm{CaCl}_{2}\right)=5.7$ and 5.9; organic matter $\left(\mathrm{g} \mathrm{dm}^{-3}\right)=22$ and 28; $\mathrm{P}_{\text {Mehlich }}\left(\mathrm{mg} \mathrm{dm}^{-3}\right)=7.7$ and $8.7 ; \mathrm{K}$ $\left(\mathrm{mg} \mathrm{dm}^{-3}\right)=250.0$ and 155.60; $\mathrm{Ca}$ and $\mathrm{Mg}\left(\mathrm{cmol}_{\mathrm{c}} \mathrm{dm}^{-3}\right)=4.9$ and $3.7 ; 1.6$ and 0.9 , respectively for the first and second experiment. In relation to texture, the soil in the first experiment was classified as very clayey, 610,120 and $270 \mathrm{~g} \mathrm{~kg}^{-1}$ clay, silt and sand, respectively; the soil in the second experiment was classified as clayey, 590, 368 and $42 \mathrm{~g} \mathrm{~kg}^{-1}$ clay, silt and sand, respectively.

The soil was plowed once and harrowed twice, after which it was treated with a rotating hoe. Mechanized planting was performed using a planter Grimme, on April 14, 2016, in the first experiment, and July 2, 2016 in the second experiment, spacing $80 \mathrm{~cm}$ between lines, planting four potato seeds (type 2 and $45 \mathrm{~mm}$ diameter) per meter, $5 \mathrm{~cm}$ depth. Base fertilizations consisted of $2300 \mathrm{~kg} \mathrm{ha}^{-1}$ of NPK formulation (03-35-06). At 25 days after planting (DAP), in the first experiment, and at 27 DAP in the second experiment, cover fertilization was carried out using 350 $\mathrm{kg} \mathrm{ha}^{-1}$ NPK formulation (20-00-20). Hilling up was done simultaneously, 4 days before post-emergence application, in the first experiment and, 7 days, in the second experiment.

Plots consisted of $2.4 \mathrm{~m}$ width (three lines of potatoes) and $5.0 \mathrm{~m}$ length, with the second plot line (central position) $3.0-\mathrm{m}$ length considered as useful area, totalizing $2.4 \mathrm{~m}^{2}$.

All plots were kept without weeds until harvest, with manual elimination of all weeds that survived chemical treatment in the control and all weeds that grew in the treatment without herbicide (control).

Potato plants were sprayed with postemergence herbicide ethoxysulfuron, four to seven days after hilling. Preemergence herbicides were sprayed after potato planting. The authors used a $\mathrm{CO}_{2}$ pressurized costal sprayer, equipped with a bar containing four spray nozzles, TTI 110015 , spaced $0.5 \mathrm{~m}$, with constant pressure of $3.4 \mathrm{kgf} \mathrm{cm}^{-2}$, with equivalent consumption of $200 \mathrm{~L} \mathrm{ha}^{-1}$.

Due to planting time (winter season), the areas were irrigated using a center pivot irrigation system and the plants received the volume of water recommended for the crop throughout the cycle. Irrigation followed the routine of the rest of the commercial area and was performed every 48 hours, in a volume of $10 \mathrm{~mm}$. In order to avoid pest and disease, insecticides and fungicides were sprayed in the experiments every week, and then the rest of the commercial area was also sprayed with these insecticides and fungicides.

Possible visual injuries in potato plants were evaluated 15,30 and 45 days after application (DAA) of postemergence herbicide ethoxysulfuron and 30, 45 and 60 DAA of pre-emergence other herbicides, making up the first, second and third evaluation periods, respectively; we used grading scale from 0 to $100 \%$, in which zero represents absence of visual injuries and 100 the death of all plants in the useful area (SBCPD, 1995).

On the harvest date (August 1, 2016, in the first experiment, September 29, 2016, in the second experiment), potato plants in the useful area of plots were counted and data were estimated for plant population per hectare (hundred plants $\mathrm{ha}^{-1}$ ). Afterwards, tubers were manually taken from the soil and, then, separated into commercial (first class: diameter $>45 \mathrm{~mm}$, second class: diameter: 20-44 $\mathrm{mm}$, and total), and discarded, counted and weighed to obtain the quantity and fresh mass of tubers per plot. Values were estimated on tha ${ }^{-1}$ and a thousand/units ha ${ }^{-1}$, respectively for productivity and quantity of commercial and discarded tubers.

For commercial productivity, only 
perfect tubers were considered (absence of deformation, cracks and no attacks of insects, fungi or bacteria), which showed diameter $>20 \mathrm{~mm}$; the others were classified as discarded tubers. Reference values of traits were estimated in relation to market trading (mainly Ceasa, DF) with the rural farmer, who lent the areas where the experiments were carried out.

In both experiments, the experimental design was randomized blocks, arranged in a factorial scheme $7 \times 2+1$, four replicates. The treatments consisted of seven herbicides applied at two doses (ethoxysulfuron 45 and $90 \mathrm{~g} \mathrm{ha}^{-1}$, halosulfuron 37.5 and 75 $\mathrm{g} \mathrm{ha}^{-1}$, sulfentrazone 250 and 500 $\mathrm{g}^{\mathrm{h}} \mathrm{a}^{-1}$, flumioxazin 17.5 and $35 \mathrm{~g}$ $\mathrm{ha}^{-1}$, clomazone 200 and $400 \mathrm{~g} \mathrm{ha}^{-1}$, isoxaflutole 37.5 and $75 \mathrm{~g} \mathrm{ha}^{-1}$ and oxadiazon 250 and $500 \mathrm{~g} \mathrm{ha}^{-1}$ ), and one herbicide-free control, kept weed-free (manual weed picking).

Joint analysis of variance was performed using SAS statistics program v. 8.2 (Muller \& Fetterman, 2003), fixed effect of both experiments (first and second) and factorial scheme of each of them were considered. The effects of experiments, herbicides, doses and their interaction, when significant, were unfolded and compared using ScottKnott test, 5\% significance level. We used the adjusted averages obtained from SAS analysis of variance to perform clustering test with the aid of Genes program Version 2013.5.1 (Cruz, 2013). Herbicide-free control was compared with treatments of interest through contrasts.

\section{RESULTS AND DISCUSSION}

ANOVA $F$ test scores for all evaluated traits are shown in Table 1. For phytointoxication notes, significant effects of interaction between the experiments, herbicides and doses, in the three evaluation times, could be noticed. The authors decided to unfold herbicide $x$ dose interaction in each experiment (Tables 2 and 3). In both experiments, the herbicide ethoxysulfuron, at two doses, caused severe visual injuries to potatoes, $34-65 \%$ in the first evaluation time. This is due to application, postemergence herbicide, when the plant shoot was exposed to the product. These notes decreased over time, due to plant recovery, which was faster in the second experiment than in the first. Ethoxysulfuron was applied on July 6, in the second experiment and on May 13 in the first experiment, when the plants showed around $10 \mathrm{~cm}$ (in the second) and $12 \mathrm{~cm}$ height (in the first). The months when the herbicide was applied (May and July) affected plant recovery; this may have occurred because of weather conditions.

In another study, the authors reported that potato plants sprayed with sulfentrazone and halosulfuron, pre and post-emergence, were more sensitive to post-emergence herbicides (Grichar et al., 2003). The same was observed for sulfentrazone (Balley et al., 2002) and flumioxazin (Vasilakoglou et al., 2013) application. Applying herbicide on the plant shoot area favors higher retention and absorption, consequently, if the plant has no metabolic or biochemical selectivity to the product, harmful effects will be more drastic. This kind of selectivity allows the plant to alter or degrade the chemical structure of the herbicide through reactions which result in non-toxic substances (Oliveira Junior \& Inoue, 2011).

Considering the other herbicides, only flumioxazin and the highest dose of clomazone, in the second experiment, caused phytointoxicaton to the crop. For flumioxazin, the symptoms were mild (less than $5 \%$ ), characterized by browning of leaves, which could not be noticed anymore at 30 DAA. In another study, this herbicide also caused phytointoxication to potato plant cv. Russet Burbank, showing notes from 1 to $19 \%$, when doses of 53 , 105 and $140 \mathrm{~g} \mathrm{ha}^{-1}$ were applied in preemergence (Hutchinson et al., 2005b). For clomazone, phytointoxication was noticed from 45 DAA on, with

Table 1. ANOVAF test scores for phytointoxication notes in three evaluation times ${ }^{1}$, besides production and quantity of commercial tubers (diameter $>45 \mathrm{~mm},<44 \mathrm{~mm}$ and total), plant population (pop.), production (Prod.) and quantity (Quant.) of discarded tuber of potato cv. Agata, in relation to experiments, herbicides, doses and interaction of factors. Cristalina-GO and Unaí-MG, Embrapa Hortaliças, 2016.

\begin{tabular}{|c|c|c|c|c|c|c|}
\hline \multirow{2}{*}{ Variation sources } & \multicolumn{3}{|c|}{ Phytointoxicaton - time } & \multicolumn{3}{|c|}{ Commercial production } \\
\hline & $1^{\text {st }}$ & $2^{\text {nd }}$ & $3^{\text {rd }}$ & $\phi>45$ & $20>\phi<44$ & Total \\
\hline Experiment & $30.2 * *$ & $21.6 * *$ & $12.8 * *$ & $1.9^{\mathrm{ns}}$ & $10.1 * *$ & $5.5^{*}$ \\
\hline Herbicide & $1035.8 * *$ & $694.1 * *$ & $162.6 * *$ & $3.0 *$ & $1.5^{\mathrm{ns}}$ & $4.4 * *$ \\
\hline Dose & $22.7 * *$ & $95.4 * *$ & $24.9 * *$ & $0.2^{\mathrm{ns}}$ & $5.8^{*}$ & $1.4^{\mathrm{ns}}$ \\
\hline Exp. $x$ herbicide & $17.9 * *$ & $60.6^{* *}$ & $33.3 * *$ & $0.2^{\mathrm{ns}}$ & $0.6^{\mathrm{ns}}$ & $0.2^{\mathrm{ns}}$ \\
\hline Exp. $x$ dose & $16.4 * *$ & $18.1 * *$ & $0.2^{\mathrm{ns}}$ & $1.4^{\mathrm{ns}}$ & $0.0^{\mathrm{ns}}$ & $1.6^{\mathrm{ns}}$ \\
\hline Herbicide $\mathrm{x}$ dose & $21.2 * *$ & $55.2 * *$ & $11.9 * *$ & $1.1^{\mathrm{ns}}$ & $0.9^{\text {ns }}$ & $0.9^{\text {ns }}$ \\
\hline Exp. $\mathrm{x}$ herb. $\mathrm{x}$ dos. & $18.5 * *$ & $7.6^{* *}$ & $8.0 * *$ & $0.4^{\mathrm{ns}}$ & $2.3^{\mathrm{ns}}$ & $0.2^{\mathrm{ns}}$ \\
\hline \multirow[t]{3}{*}{$\mathrm{CV}(\%)$} & 31.2 & 36.2 & 72.1 & 16.3 & 30.1 & 13.5 \\
\hline & \multicolumn{3}{|c|}{ Commercial quantity } & \multirow{2}{*}{ Pop. } & \multicolumn{2}{|c|}{ Discarded } \\
\hline & $\phi>45$ & $20>\phi<44$ & Total & & Prod. & Quant. \\
\hline Experiment & $42.6^{* *}$ & $19.5^{* *}$ & $59.1 * *$ & $7.6^{* *}$ & $2.7^{\mathrm{ns}}$ & $144.2 * *$ \\
\hline Herbicide & $3.7^{*}$ & $2.0^{*}$ & $4.3 * *$ & $1.1^{\mathrm{ns}}$ & $2.0^{\mathrm{ns}}$ & $0.2^{\mathrm{ns}}$ \\
\hline Dose & $0.9^{\text {ns }}$ & $7.3 * *$ & $4.9^{*}$ & $0.0^{\mathrm{ns}}$ & $1.2^{\mathrm{ns}}$ & $1.2^{\mathrm{ns}}$ \\
\hline Exp. $x$ herbicide & $0.4^{\mathrm{ns}}$ & $0.8^{\mathrm{ns}}$ & $0.3^{\mathrm{ns}}$ & $1.8^{\mathrm{ns}}$ & $0.5^{\mathrm{ns}}$ & $1.2^{\mathrm{ns}}$ \\
\hline Exp. $x$ dose & $2.1^{\mathrm{ns}}$ & $0.3^{\mathrm{ns}}$ & $1.9^{\mathrm{ns}}$ & $0.0^{\mathrm{ns}}$ & $0.5^{\mathrm{ns}}$ & $0.4^{\mathrm{ns}}$ \\
\hline Herbicide $\mathrm{x}$ dose & $0.6^{\mathrm{ns}}$ & $0.7^{\mathrm{ns}}$ & $0.8^{\mathrm{ns}}$ & $1.0^{\mathrm{ns}}$ & $1.1^{\mathrm{ns}}$ & $2.3^{*}$ \\
\hline Exp. $\mathrm{x}$ herb. $\mathrm{x}$ dos. & $0.4^{\mathrm{ns}}$ & $2.0^{\mathrm{ns}}$ & $0.9^{\text {ns }}$ & $1.7^{\mathrm{ns}}$ & $1.6^{\mathrm{ns}}$ & $3.9 * *$ \\
\hline $\mathrm{CV}(\%)$ & 14.9 & 26.7 & 13.3 & 9.9 & 61.9 & 34.9 \\
\hline
\end{tabular}

${ }^{1}$ At 15,30 and 45 days after application (DAA) of post-emergence ethoxysulfuron; and at 30,45 and 60 DAA application of other herbicides, pre-emergence application. **, *Significant at $1 \%$

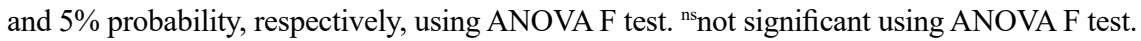


notes ranging from $14 \%$ (45 DAA) to $12 \%$ (60 DAA), and symptoms were characterized by chlorotic spots among leaf veins. Visual damages might have occurred late, since with plant developing, the roots had access to herbicide in soil profile. Clomazone and flumioxazin movement through soil profile should also be considered, high and small, respectively. High clomazone and small flumixazin movements through soil profile should also be considered. Herbicide movement in soil depends on the soil physico-chemical characteristics and climatic conditions.

In most cases, tolerance or susceptibility of a plant to herbicides varies depending on the product (independently of the mechanism of

Table 2. Averages of phytointoxication notes of the first and second evaluation times $^{1}$ of potato cv. Agata, in relation to unfolded triple interaction (experiment x herbicide x doses), and herbicide-free control. Cristalina-GO and Unaí-MG, Embrapa Hortaliças, 2016.

\begin{tabular}{|c|c|c|c|c|}
\hline \multirow{4}{*}{ Herbicides/control } & \multicolumn{4}{|c|}{$1^{\text {st }}$ evaluation - Phytointoxication (\%) } \\
\hline & \multicolumn{2}{|c|}{$1^{\text {st }}$ research (Unaí) } & \multicolumn{2}{|c|}{$2^{\text {nd }}$ research (Cristalina) } \\
\hline & \multicolumn{4}{|c|}{ Doses } \\
\hline & Lower & Higher & Lower & Higher \\
\hline Ethoxysulfuron & $63.8 \mathrm{~b} \mathrm{~A}^{(2)}$ & $65.0 \mathrm{~b} \mathrm{~A}$ & $33.8 \mathrm{~b} \mathrm{~A}$ & $65.0 \mathrm{~b} \mathrm{~B}$ \\
\hline Halosulfuron & $0.0 \mathrm{a} \mathrm{A}$ & $0.0 \mathrm{a} \mathrm{A}$ & $0.0 \mathrm{a} \mathrm{A}$ & $0.0 \mathrm{a} \mathrm{A}$ \\
\hline Sulfentrazone & $0.0 \mathrm{a} \mathrm{A}$ & $0.0 \mathrm{a} \mathrm{A}$ & $0.0 \mathrm{a} \mathrm{A}$ & $0.0 \mathrm{a} \mathrm{A}$ \\
\hline Flumioxazin & $3.8 \mathrm{a} \mathrm{A}$ & $5.0 \mathrm{a} \mathrm{A}$ & $0.0 \mathrm{a} \mathrm{A}$ & $0.0 \mathrm{a} \mathrm{A}$ \\
\hline Clomazone & $0.0 \mathrm{a} \mathrm{A}$ & $0.0 \mathrm{a} \mathrm{A}$ & $0.0 \mathrm{a} \mathrm{A}$ & $0.0 \mathrm{a} \mathrm{A}$ \\
\hline Isoxaflutole & $0.0 \mathrm{a} \mathrm{A}$ & $0.0 \mathrm{a} \mathrm{A}$ & $0.0 \mathrm{a} \mathrm{A}$ & $0.0 \mathrm{a} \mathrm{A}$ \\
\hline Oxadiazon & $0.0 \mathrm{a} \mathrm{A}$ & $0.0 \mathrm{a} \mathrm{A}$ & $0.0 \mathrm{a} \mathrm{A}$ & $0.0 \mathrm{a} \mathrm{A}$ \\
\hline \multirow[t]{5}{*}{ Control } & \multicolumn{2}{|c|}{0.0} & \multicolumn{2}{|c|}{$\begin{array}{c}0.0 \\
\end{array}$} \\
\hline & \multicolumn{4}{|c|}{$2^{\text {nd }}$ evaluation - Phytointoxication (\%) } \\
\hline & \multicolumn{2}{|c|}{$1^{\text {st }}$ research (Unaí) } & \multicolumn{2}{|c|}{$2^{\text {nd }}$ research (Cristalina) } \\
\hline & \multicolumn{4}{|c|}{ Doses } \\
\hline & Lower & Higher & Lower & Higher \\
\hline Ethoxysulfuron & $41.2 \mathrm{~b} \mathrm{~A}$ & $57.5 \mathrm{~b} \mathrm{~B}$ & $15.0 \mathrm{~b} \mathrm{~A}$ & $42.5 \mathrm{c} \mathrm{B}$ \\
\hline Halosulfuron & $0.0 \mathrm{a} \mathrm{A}$ & $0.0 \mathrm{a} \mathrm{A}$ & $0.0 \mathrm{a} \mathrm{A}$ & $0.0 \mathrm{a} \mathrm{A}$ \\
\hline Sulfentrazone & $0.0 \mathrm{a} \mathrm{A}$ & $0.0 \mathrm{a} \mathrm{A}$ & $0.0 \mathrm{a} \mathrm{A}$ & 0.0 a $\mathrm{A}$ \\
\hline Flumioxazin & $0.0 \mathrm{a} \mathrm{A}$ & $0.0 \mathrm{a} \mathrm{A}$ & $0.0 \mathrm{a} \mathrm{A}$ & 0.0 a $\mathrm{A}$ \\
\hline Clomazone & $0.0 \mathrm{a} \mathrm{A}$ & $0.0 \mathrm{a} \mathrm{A}$ & $0.0 \mathrm{a} \mathrm{A}$ & $13.8 \mathrm{~b} \mathrm{~A}$ \\
\hline Isoxaflutole & $0.0 \mathrm{a} \mathrm{A}$ & $0.0 \mathrm{a} \mathrm{A}$ & $0.0 \mathrm{a} \mathrm{A}$ & $0.0 \mathrm{a} \mathrm{A}$ \\
\hline Oxadiazon & $0.0 \mathrm{a} \mathrm{A}$ & $0.0 \mathrm{a} \mathrm{A}$ & $0.0 \mathrm{a} \mathrm{A}$ & $0.1 \mathrm{a} \mathrm{A}$ \\
\hline Control & \multicolumn{2}{|c|}{0.0} & \multicolumn{2}{|c|}{0.0} \\
\hline
\end{tabular}

${ }^{1}$ At 15 and 30 days after (DAA) post-emergence application of ethoxysulfuron; and at 30 and 45 DAA pre-emergence application of other herbicides. ${ }^{2}$ Using Scott-Knott test at $5 \%$ probability, averages followed by uppercase letter, in columns, compare herbicides within each dose and uppercase letter, in lines, compare doses within each herbicide, for the respective evaluated variable. triazolinones, respectively (Rodrigues \& Almeida, 2018). The same for clomazone and isoxaflutole, which are inhibitors of carotenoid synthesis, belong to isoxazolidinones and isoxazoles chemical groups, respectively (Rodrigues \& Almeida, 2018).

Interaction of the three factors was also significant for quantity of discarded tubers (Table 3 ). In the first experiment, the highest doses of herbicide ethoxysulfuron and halosulfuron differed from the others and their respective lowest doses. The same was observed for the lowest dose of sulfentrazone. These treatments differed from herbicide-free control and resulted in lower quantity of discarded tubers. On the other hand, in the second experiment, at these two doses, no significant difference between herbicides and the control was observed. In relation to discarded tubers, in both experiments, interactions and isolated factors were not significant.

Significant interactions were observed only for isolated factors and no significant interactions for any other evaluated trait were observed. For plant population and commercial tuber production with diameter under $44 \mathrm{~mm}$, herbicides did not differ among each other. However, for production of larger tubers (diameter $>45 \mathrm{~mm}$ ) and total production, ethoxysulfuron differed from the other herbicides and control, resulting in lower averages (Table 4). The same was verified for quantity of commercial tubers (diameter $>45 \mathrm{~mm}$, diameter $<44 \mathrm{~mm}$ and total), added halosulfuron and sulfentrazone, which also resulted in lower average. These three herbicides differed from the others and herbicide-free control.

In another study, herbicides halosulfuron and sulfentrazone affected total potato tuber production, in the three places where the experiment took place, mainly in the highest doses (210 and $280 \mathrm{~g} \mathrm{ha}^{-1}$ of sulfentrazone and $66 \mathrm{~g} \mathrm{ha}^{-1}$ of halosulfuron) and when the herbicides were sprayed in postemergence herbicides (Grichar et al., 2003). Results obtained from clayey soil with low organic matter content $(<1.0 \%)$. In the present study, soil in both experiments was clayey and very 
Table 3. Averages of phytointoxication notes of third evaluation time ${ }^{1}$ and quantity of discarded tubers of potato cv. Agata, in relation to unfolding of the triple interaction (experiment $\mathrm{x}$ herbicide $\mathrm{x}$ doses), and control without application. Cristalina-GO and UnaíMG, Embrapa Hortaliças, 2016.

\begin{tabular}{|c|c|c|c|c|}
\hline \multirow{4}{*}{$\begin{array}{l}\text { Herbicides/ } \\
\text { control }\end{array}$} & \multicolumn{4}{|c|}{$3^{\text {rd }}$ evaluation - Phytointoxication (\%) } \\
\hline & \multicolumn{2}{|c|}{$1^{\text {st }}$ research (Unaí) } & \multicolumn{2}{|c|}{$2^{\text {nd }}$ research (Cristalina) } \\
\hline & \multicolumn{4}{|c|}{ Doses } \\
\hline & Lower & Higher & Lower & Higher \\
\hline Ethoxysulfuron & $25.0 \mathrm{~b} \mathrm{~A}^{(2)}$ & $46.2 \mathrm{~b} \mathrm{~B}$ & $12.5 \mathrm{~b} \mathrm{~A}$ & $17.5 \mathrm{c} \mathrm{B}$ \\
\hline Halosulfuron & 0.0 a $\mathrm{A}$ & $0.0 \mathrm{a} \mathrm{A}$ & 0.0 a $\mathrm{A}$ & $0.0 \mathrm{a} A$ \\
\hline Sulfentrazone & $0.0 \mathrm{a} \mathrm{A}$ & $0.0 \mathrm{a} \mathrm{A}$ & $0.0 \mathrm{a} \mathrm{A}$ & $0.0 \mathrm{a} \mathrm{A}$ \\
\hline Flumioxazin & $0.0 \mathrm{a} \mathrm{A}$ & $0.0 \mathrm{a} \mathrm{A}$ & $0.0 \mathrm{a} A$ & $0.0 \mathrm{a} \mathrm{A}$ \\
\hline Clomazone & 0.0 a $\mathrm{A}$ & $0.0 \mathrm{a} \mathrm{A}$ & $0.0 \mathrm{a} \mathrm{A}$ & $12.5 \mathrm{~b} \mathrm{~B}$ \\
\hline Isoxaflutole & $0.0 \mathrm{a} \mathrm{A}$ & $0.0 \mathrm{a} \mathrm{A}$ & $0.0 \mathrm{a} \mathrm{A}$ & $0.0 \mathrm{a} \mathrm{A}$ \\
\hline Oxadiazon & $0.0 \mathrm{a} \mathrm{A}$ & $0.0 \mathrm{a} \mathrm{A}$ & $0.0 \mathrm{a} \mathrm{A}$ & $0.6 \mathrm{a} \mathrm{A}$ \\
\hline \multirow[t]{5}{*}{ Control } & \multicolumn{2}{|c|}{0.0} & \multicolumn{2}{|c|}{0.0} \\
\hline & \multicolumn{4}{|c|}{ Quantity of discarded tubers (thousand/units ha-1) } \\
\hline & \multicolumn{2}{|c|}{$1^{\text {st }}$ research (Unaí) } & \multicolumn{2}{|c|}{$2^{\text {nd }}$ research (Cristalina) } \\
\hline & \multicolumn{4}{|c|}{ Doses } \\
\hline & Lower & Higher & Lower & Higher \\
\hline Ethoxysulfuron & $149.1 \mathrm{a} \mathrm{A}$ & $72.3 \mathrm{~b} B$ & 48.9 a $\mathrm{A}$ & 61.5 a $\mathrm{A}$ \\
\hline Halosulfuron & $132.1 \mathrm{a} \mathrm{A}$ & $81.2 \mathrm{~b} \mathrm{~B}$ & 44.8 a $\mathrm{A}$ & 47.9 a $\mathrm{A}$ \\
\hline Sulfentrazone & $75.0 \mathrm{~b} \mathrm{~B}$ & 146.4 a $\mathrm{A}$ & 65.6 a $\mathrm{A}$ & 42.7 a $\mathrm{A}$ \\
\hline Flumioxazin & 122.3 a $\mathrm{A}$ & 138.1 a $\mathrm{A}$ & 37.5 a $\mathrm{A}$ & 52.1 a A \\
\hline Clomazone & 141.9 a A & 110.7 a A & 47.9 a A & $29.2 \mathrm{a} \mathrm{A}$ \\
\hline Isoxaflutole & $116.1 \mathrm{a} \mathrm{A}$ & 118.8 a A & $53.1 \mathrm{a} \mathrm{A}$ & 44.8 a A \\
\hline Oxadiazon & $101.2 \mathrm{a} \mathrm{A}$ & 103.6 a A & $55.2 \mathrm{a} \mathrm{A}$ & $59.2 \mathrm{a} \mathrm{A}$ \\
\hline Control & \multicolumn{2}{|c|}{146.4} & \multicolumn{2}{|c|}{53.1} \\
\hline
\end{tabular}

${ }^{1}$ At 45 days after application (DAA) of post-emergence ethoxysulfuron; and at 60 DAA application of other herbicides, pre-emergence application. ${ }^{2}$ Using Scott-Knott test at 5\% probability, averages followed by lowercase letter, in columns, compare herbicides within each dose and uppercase letter, in lines, compare doses within each herbicide, for the respective evaluated variable.

clayey, with medium organic matter content (2.2 and $2.8 \%)$. The type of soil and organic matter content interfere in bioavailability of herbicides in soil solution, being able to be absorbed by plants, lost through leaching, volatilization or degraded.

Herbicide doses (Table 5) influenced in production and quantity of tubers with diameters under $44 \mathrm{~mm}$, and total quantity of tubers as well, in which the highest averages were obtained with the lowest doses of herbicides, not differing from the control. For plant population, production of larger commercial tubers, total production of tubers and quantity of larger tubers (diameter $>45 \mathrm{~mm}$ ), no significant difference between doses (lowest and highest) and the studied herbicides was noticed.

In addition to soil characteristics, potato genotype can also influence selectivity, which is explained by changes related to plant uptake, translocation, metabolization or even compartmentalization. In relation to these, cultivar Ranger Russet was the most sensitive to herbicides flumioxazin and sulfentrazone compared to the other tested cultivars (Russet Burbank, Russet Norkotah and Shepody), which did not show potato tuber production affected by herbicides (Hutchinson et al., 2005b).

In relation to experiments (Table 6 ), higher quantity of commercial tubers (diameter $>45 \mathrm{~mm}$, diameter $<44$ $\mathrm{mm}$ and total) was verified in the first experiment when compared with the second one. However, for commercial tuber production, the second experiment showed higher average, except for $>45$ $\mathrm{mm}$ tubers, which no difference between experiments was noticed. Besides, in the first experiment, the authors noticed higher plant population. Comparing the controls in both experiments, the authors verified the same relation observed for the averages of treatments with herbicide application, except for plant population, where the control of the second experiment showed higher average compared with the control of the first experiment.

Differences between the experiments are justified due to planting time (April, in the first, and June, in the second), which affected cultivar Agata. Seed potato size and form of planting could also explain those differences. Nevertheless, seed potatoes of the same caliber were used in both experiments (type 2), mechanic planting using the planter Grimme. As observed for herbicide treatments, the number of commercial tubers was more responsive to studied factors than fresh mass (production) of tubers, since the response variability was higher.

The hypothesis that there is a variation in the phytotoxic action of the herbicides ethoxysulfuron, halosulfuron, sulfentrazone, flumioxazin, clomazone, isoxaflutole and oxadiazon on potato crop was confirmed for ethoxysulfuron, flumioxazin and clomazone for phytotoxicity symptoms on potato; ethoxysulfuron, for production and quantity of commercial tubers; halosulfuron and sulfentrazone for quantity of smaller and total commercial tubers. Considering total production of commercial tubers and tubers with higher diameter, plant response to ethoxysulfuron was more pronounced and relevant, justified by the time of herbicide application (post-emergence application).

Based on phytotoxicity notes and production of commercial tubers (especially, total and diameter higher than $45 \mathrm{~mm}$ ), the herbicides flumioxazin, halosulfuron, sulfentrazone, clomazone, isoxaflutole and oxadiazon, at two tested doses, were considered selective 
Table 4. Averages of production (diameter $>45 \mathrm{~mm}$ and total) and quantity of commercial tubers (diameter $>45 \mathrm{~mm},<44 \mathrm{~mm}$ and total) of potato cv. Agata, in relation to herbicides (isolated factor), and herbicide-free control. Cristalina-GO and Unaí-MG, Embrapa Hortaliças, 2016.

\begin{tabular}{|c|c|c|c|c|c|}
\hline \multirow{2}{*}{$\begin{array}{l}\text { Herbicides/ } \\
\text { controls }\end{array}$} & \multicolumn{2}{|c|}{ Production (t ha-1) } & \multicolumn{3}{|c|}{ Quantity (thousand/units ha') } \\
\hline & $\phi<45$ & Total & $\phi>45$ & $20>\phi<44$ & Total \\
\hline Ethoxysulfuron & $39.2 b^{(1)}$ & $45.0 \mathrm{~b}$ & $234.8 \mathrm{~b}$ & $108.2 \mathrm{~b}$ & $343.0 \mathrm{~b}$ \\
\hline Halosulfuron & $46.4 \mathrm{a}$ & $52.7 \mathrm{a}$ & $278.5 \mathrm{a}$ & $99.3 \mathrm{~b}$ & $377.8 \mathrm{~b}$ \\
\hline Sulfentrazone & $44.8 \mathrm{a}$ & $51.1 \mathrm{a}$ & $269.4 \mathrm{a}$ & $110.1 \mathrm{~b}$ & $379.5 \mathrm{~b}$ \\
\hline Flumioxazin & $44.9 \mathrm{a}$ & $51.9 \mathrm{a}$ & $288.8 \mathrm{a}$ & $123.1 \mathrm{a}$ & $411.9 \mathrm{a}$ \\
\hline Clomazone & $46.7 \mathrm{a}$ & $53.9 \mathrm{a}$ & $285.7 \mathrm{a}$ & $128.9 \mathrm{a}$ & $414.7 \mathrm{a}$ \\
\hline Isoxaflutole & $48.9 \mathrm{a}$ & $55.6 \mathrm{a}$ & $293.5 \mathrm{a}$ & $120.2 \mathrm{a}$ & $413.7 \mathrm{a}$ \\
\hline Oxadiazon & $48.6 \mathrm{a}$ & $56.1 \mathrm{a}$ & $287.2 \mathrm{a}$ & $126.9 \mathrm{a}$ & $409.3 \mathrm{a}$ \\
\hline Control & 45.6 & 53.6 & 279.8 & 151.3 & 431.1 \\
\hline
\end{tabular}

${ }^{1}$ Using Scott-Knott test at $5 \%$ probability, averages followed by lowercase letter, in columns, compare herbicides within each evaluated variable.

Table 5. Average production (diameter $<44 \mathrm{~mm}$ ) and quantity of commercial tubers (diameter $<44 \mathrm{~mm}$ and total) of potato cv. Agata, in relation to studied doses (isolated factor), and herbicide-free control. Cristalina-GO and Unaí-MG, Embrapa Hortaliças, 2016.

\begin{tabular}{lcccc}
\hline \multirow{2}{*}{$\begin{array}{l}\text { Doses } / \\
\text { controls }\end{array}$} & Production (t ha & & & \multicolumn{2}{c}{ Quantity (thousand/units ha $\mathbf{~}^{-1}$ ) } \\
\cline { 2 - 4 } \cline { 5 - 6 } & $\mathbf{2 0}>\phi<\mathbf{4 4}$ & & $\mathbf{2 0}>\phi<\mathbf{4 4}$ & Total \\
\hline Lower & $7.2 \mathrm{a}^{(1)}$ & & $124.8 \mathrm{a}$ & $403.9 \mathrm{a}$ \\
Higher & $6.2 \mathrm{~b}$ & & $108.5 \mathrm{~b}$ & $381.9 \mathrm{~b}$ \\
\hline Control & 8.0 & & 151.3 & 431.1 \\
\hline
\end{tabular}

${ }^{1}$ Using Scott-Knott test at $5 \%$ probability, averages followed by lowercase letter, in columns, compare doses within each evaluated variable.

Table 6. Averages of plant population, production (diameter $<44 \mathrm{~mm}$ and total) and quantity of commercial tubers (diameter $>45,<44 \mathrm{~mm}$ and total) of potato cv. Agata, in relation to experiments carried out in Unaí, MG (first) and Cristalina, GO (second), and herbicide-free controls of each experiment. Cristalina-GO and Unaí-MG, Embrapa Hortaliças, 2016.

\begin{tabular}{|c|c|c|c|c|c|c|}
\hline \multirow{2}{*}{\multicolumn{2}{|c|}{ Experiments Population }} & \multicolumn{2}{|c|}{ Production $\left(\mathrm{t} \mathrm{ha}^{-1}\right)$} & \multicolumn{3}{|c|}{ Quantity (thousand/units ha ${ }^{-1}$ ) } \\
\hline & & $20>\phi<44$ & Total & $\phi>45$ & $20>\phi<44$ & Total \\
\hline First & $44.8 \mathrm{a}$ & $6.1 \mathrm{~b}$ & $50.8 \mathrm{~b}$ & $302.4 \mathrm{a}$ & 129.9 a & $431.1 \mathrm{a}$ \\
\hline Second & $42.5 \mathrm{~b}$ & $7.3 \mathrm{a}$ & $53.9 \mathrm{a}$ & $251.3 \mathrm{~b}$ & $103.4 \mathrm{~b}$ & $354.7 \mathrm{~b}$ \\
\hline Contr & 42.9 & 7.68 & 52.8 & 305.4 & 183.9 & 489.3 \\
\hline Control $2^{\text {nd }}$ & 44.8 & 8.36 & 54.4 & 254.2 & 118.8 & 372.9 \\
\hline
\end{tabular}

${ }^{1}$ Using Scott-Knott test at 5\% probability, averages followed by lowercase letter, in columns, compare experiments within each evaluated variable.

for potato crop cv. Agata, even with variations in quantity of tubers, but without effect on fresh mass. These results are important since they will be used for further studies as well as for possible registration of herbicides halosulfuron, sulfentrazone and oxadiazon for potato crop. Herbicides clomazone, flumioxazin and isoxaflutole, already registered, are options for weed management as they can also be used by the crop farmers.

Pre-emergence herbicides flumioxazin, halosulfuron, sulfentrazone, clomazone, isoxaflutole and oxadiazon sprayed after planting, at two tested doses, were selective for potato crop cv. Agata.

\section{ACKNOWLEDGEMENTS}

Thanks to Agrícola Wehrmann, specifically agricultural engineer Rodrigo Ribeiro, the production manager, who provided the areas for the field experiments.

\section{REFERENCES}

AGROFIT. 2019. Sistema de Agrotóxicos Fitossanitários do MAPA. available http:// agrofit.agricultura.gov.br/agrofit_cons/ principal_agrofit_cons Accessed August 23, 2019.

BAILEY, WA; WILSON, HP; HINES, TE. 2002. Response of potato (Solanum tuberosum) and selected weeds to sulfentrazone. Weed Technology 16: 651-658.

BOYD, NS. 2015. Evaluation of preemergence herbicides for purple nutsedge (Cyperus rotundus) control in tomato. Weed Technology 29: 480-487.

BOYDSTON, RA. 2007. Potato and weed response to postemergence-applied halosulfuron, rimsulfuron, and EPTC. Weed Technology 21: 465-469.

CARDOSO, MR; MARCUZZO, FF; BARROS, JR. 2014. Classificação climática de KöppenGeiger para o estado de Goiás e Distrito Federal. Acta Geográfica 8: 40-55.

CRUZ, CD. 2013. Genes: a software package for analysis in experimental statistics and quantitative genetics. Acta Scientiarum Agronomy 35: 271-276.

GANNON, TW; YELVERTON, FH; TREDWAY, LP. 2012. Selective exposure of yellow nutsedge (Cyperus esculentus), purple nutsedge (Cyperus rotundus), and false green kyllinga (Kyllinga gracillima) to postemergence herbicides. Weed Technology 26: 294-299.

GRICHAR, WJ; BESLER, BA; BREWER, KD. 2003. Purple nutsedge control and potato (Solanum tuberosum) tolerance to sulfentrazone and halosulfuron. Weed Technology 17: 485-490.

HUTCHINSON, PJS; HANCOCK, DM; BEUTLER, BR. 2005a. Efficacy of reduced sulfentrazone rates applied preemergence with metribuzin in potato (Solanum tuberosum). Weed Technology 19: 954-958.

HUTCHINSON, PJS; BOYDSTON RA; RANSOM, CV; TONKS, DJ. 2005b. Potato variety tolerance to flumioxazin and sulfentrazone. Weed Technology 19: 683-696.

HUTCHINSON, PJS; BEUTLER, BR; HANCOCK, DM. 2006. Weed control and potato (Solanum tuberosum) crop response with low rates of sulfentrazone applied postemergence with metribuzin. Weed Technology 20: 1023-1029.

HUTCHINSON, PJS. 2007. Comparison of flumioxazin and rimsulfuron tank mixtures for weed control in potato. Weed Technology 


\section{1: 1023-1028.}

KAZARIAN, DE; NISSEN, SJ; THOMPSON, AL. 2000. Sulfentrazone and flumioxazin for broadleaf control in potatoes. Proceedings Western Society Weed Science 53: 76.

LORENZI, H. 2008. Plantas daninhas do Brasil: terrestres aquáticas, parasitas e tóxicas. $4^{\mathrm{a}}$ ed., Nova Odessa: Instituto Plantarum. 672p.

MULLER, KE; FETTERMAN, BA. 2003. Regression and ANOVA: An integrated approach using SAS Software. New York: John Wiley \& Sons. 592p.

OLIVEIRA JUNIOR, RS; INOUE, MH. 2011. Seletividade de herbicidas para culturas e plantas daninhas. In: OLIVEIRA JUNIOR, RS; CONSTANTIN, J; INOUE, MH (eds). Biologia e manejo de plantas daninhas. Curitiba: Omnipax. p.243-262.

RODRIGUES, BN; ALMEIDA, FLS. 2018. Guia de herbicidas. 7. ed. Londrina: Edição dos autores. $764 \mathrm{p}$.

SBCPD - Sociedade Brasileira da Ciência das Plantas Daninhas. 1995. Procedimentos para instalação, avaliação e análise de experimentos com herbicidas. Londrina. 42p. SIMÕES, RM; RODRIGUES, M; SILVA, LF; ALVES, MA. 2015. Aspectos climáticos do estado de Minas Gerais. Revista Brasileira de
Climatologia 11: 206-226.

VA S I L A K O G L OU， I； DHIMA，K ; PASCHALIDIS, K; THOMAS GATSIS, T; ZACHARIS, K; GALANIS, M. 2013. Field bindweed (Convolvulus arvensis L.) and redroot pigweed (Amaranthus retroflexus L.) control in potato by pre- or post-emergence applied flumioxazin and sulfosulfuron. Chilean Journal of Agricultural Research 73: 24-30.

WILSON, DE; NISSEN, SJ; THOMPSON, A. 2002. Potato (Solanum tuberosum) variety and weed response to sulfentrazone and flumioxazin. Weed Technology 16: 567-574. 